\title{
PUNITIVE DAMAGES, SOCIAL NORMS, AND ECONOMIC ANALYSIS
}

\author{
ROBERT D. COOTER* \\ I \\ INTRODUCTION
}

From its beginnings, the economic analysis of law has traced the incentive effects of liability on potential wrongdoers who pursue their material advantage. ${ }^{3}$ Recently the economic analysis of law has turned to the study of social norms. ${ }^{2}$ This paper relates these two literatures to punitive damages. People

Copyright $\odot 1997$ by Law and Contemporary Problems

This article is also available at $\mathrm{http}: / / \mathrm{www}$.law.duke.edu/journals/lcp.

* Herman F. Selvin Professor of Law, University of California at Berkeley.

1. For an overview of the vast economic literature on liability, see Robert D. Cooter, Economic Theories of Legal Liability, 5 J. ECON. PERSP. 11 (Summer 1991). As for punitive damages, a symposium on the economic analysis of punitive damages was published in 1982 in Symposium, Punitive Damages, 56 S. CAL. L. REV. 1 (1982). The keynote paper is Dan Ellis, Fairness and Efficiency in the Law of Punitive Damages, 56 S. CAL. L. REV. 1 (1982). My paper in this symposium, Robert D. Cooter, Economic Analysis of Punitive Damages, 56 S. CAL. L. REV. 79 (1982), begins a discussion of the possibly central role of discontinuities in the law of negligence. Another symposium on punitive damages appeared in Symposium, Punitive Damages, 40 ALA. L. REV. 687 (1989), with economically oriented articles by Bruce Chapman and Michael Trebilcock, Robert D. Cooter, Dan Dobbs, E. Donald Elliott, Dorsey Ellis, David Friedman, Mark Grady, Peter Huber, George Priest, and Gary Schwartz. See also A. Mitchell POLINSKY \& STEVEn SHAVEll, A NOTE ON OPTIMAL FINES WheN WEALTH VARIES AMONG INDIVIDUALS (National Bureau of Econ. Research Working Paper No. 3232, 1990); Theodore Eisenberg, The Predictability of Punitive Damages, 26 J. LEGAL STUD. 623 (1997); Ellis, supra; David D. Haddock et al., An Ordinary Economic Rationale for Extraordinary Legal Sanctions, 78 CAL. L. REV. 1 (1990); Jason S. Johnston, Punitive Liability: A New Paradigm of Efficiency in Tort Law, 87 ColuM. L. REV. 1385 (1987); William Landes \& Richard Posner, An Economic Theory of Intentional Torts, 1 INT'L REV. L. \& ECON. 127 (1981); A. Mitchell Polinsky \& Steven Shavell, Punitive Damages: An Economic Analysis, 111 HARv. L. REV. 869 (1998) [hereinafter Polinsky \& Shavell, Punitive Damages]; Gary T. Schwartz, The Myth of the Ford Pinto Case, 43 RUTGERS L. REV. 1013 (1991); John E. Calfee et al., BMW v. Gore: Mitigating the Punitive Economics of Punitive Damages (1997) (paper read at the meeting of the American Law and Economics Association in Toronto); Richard Craswell, When Is a Willful Breach "Willful"? General v. Specific Deterrence in Contract Remedies (1996) (paper read at the meeting of the American Law and Economics Association in Chicago); Andrew F. Daughtey \& Jennifer Reingaum, Settlement, Deterrence, and the Economics of Punitive Damages Reform (1997) (paper read at the meeting of the American Law and Economics Association in Toronto).

2. Contributions to the burgeoning legal literature on social norms include ROBERT C. ELLICKSON, ORDER WITHOUT LAW: HOW NEIGHBORS SETTLE DISPUTES (1991); Lisa Bernstein, Social Norms and Default Rules Analysis, 3 S. CAL. INTERDISC. L. J. 59 (1993); Robert D. Cooter, Decentralized Law for a Complex Economy: The Structural Approach to Adjudicating the New Law Merchant, 144 U. PA. L. REV. 1643 (1996); Robert D. Cooter, Decentralized Law for a Complex Economy, 23 S.W. U. L. ReV. 443 (1994); Robert D. Cooter, Inventing Market Property: The Land Courts of Papua New Guinea, 25 LAw \& SOC'Y REV. 759 (1991); Lawrence Lessig, Social Meaning and Social Norms, 144 U. PENN. L. Rev. 2181 (1996); Richard H. McAdams, Cooperation and Conflict: The Economics of Group Status Production and Race Discrimination, 108 HARV. L. REV. 1003 (1984); Eric A. Posner, The Regulation of Religious Groups, 2 LEGAL THEORY 33 (1996); Lisa Bernstein, Private 
who internalize social norms feel righteous anger against those who violate them. The institution of punitive damages allows judges and juries to express righteous anger through speech and punishment. Expression of emotions by the court demonstrates the strength of its commitment to the law in question. Perception of this commitment shapes the expectations of citizens and changes their behavior. In technical terms, expressions of emotion signal commitment, and commitment provides a focal point in a game with multiple equilibria.

Conventional morality provides a basis for ordering wrongdoing by its seriousness, but conventional morality does not attach precise punishments to wrongs. Consequently, people order wrongdoing consistently by its seriousness, but they attach inconsistent money damages to wrongdoing. Social norms provide a better guide to the need for punitive damages than to their extent. Inconsistent awards of punitive damages muddle the message conveyed by the courts concerning the seriousness of the wrong. Courts should not ask juries to determine the extent of punishment without providing instructions for its computation from the facts of the case.

Consistency requires mapping wrongs ordered by seriousness into punishments ordered by severity. The goal of deterrence provides a basis for consistent punishment. ${ }^{3}$ The court in a typical case should impose the minimum punishment required to deter wrongdoing. In jury trials, the court should instruct the jury on how to compute the minimum punishment required for deterrence. ${ }^{4}$ To compute the minimum, I distinguish between intentional and unintentional wrongdoing by a theory of rational self-monitoring. Imperfect selfmonitoring results in lapses that cause unintentional violations of legal obligations. I show that liability for compensatory damages provides efficient incentives for self-monitoring. Deterring intentional wrongdoing, however, requires additional liability. In circumstances explained in Part V. B., optimal deterrence requires increasing compensatory damages by the reciprocal of the enforcement error.

Commercial Law in the Cotton Industry: Value Creation Through Rules, Norms, and Institutions (1997) (paper read at the meeting of the American Law and Economics Association in Toronto); Lisa Bernstein, The Newest Law Merchant, Private Commercial Law in the United States (1995) (paper read at the meeting of the American Law \& Economics Association in Berkeley, CA); Robert D. Cooter, Expressive Law and Economics (1997) (paper read at Social Norms, Social Meaning, and the Economic Analysis of Law, conference at University of Chicago Law School [hereinafter Chicago Social Norms Conference]); Dan Kahan, Social Meaning for Criminal Law (1997) (paper read at Chicago Social Norms Conference); Timur Kuran, From Melting Pot to Salad Bowl: Ethnic Activity and Social Induced Ethnification (1997) (paper read at Chicago Social Norms Conference); Randal C. Picker, Simple Games in a Complex World: A Generative Approach to the Adoption of Norms (1997) (paper read at the meeting of the American Law and Economics Association in Toronto); Eric A. Posner, Symbols, Signals, and Social Norms in Politics and the Law (1997) (paper read at Chicago Social Norms Conference); Cass Sunstein, Norms and Roles (1996) (paper read at the meeting of the American Law and Economics Association in Chicago). For two recent symposia on the field, see Symposium, Social Norms, 144 U. PENN. L. REV. 2055 (1996); Symposium, Social Norms, Social Meaning, and the Economic Analysis of the Law, 27 J. LEGAL STUD. (forthcoming 1998).

3. The most thorough and far-reaching application of deterrence theory to punitive damages is found in Polinsky \& Shavell, Punitive Damages, supra note 1.

4. See id. at 957 (providing sample jury instructions). 
II

\section{Punitive Damages in Practice}

"Punitive damages" usually refers to damages awarded to the plaintiff in a civil trial in order to punish the defendant. Private law in most countries prohibits or narrowly circumscribes punitive damages, perhaps because civil procedures afford less protection to the defendant than criminal procedures. United States statutes occasionally prescribe punitive damages, most notably in antitrust cases where the law allows treble damages. ${ }^{5}$ However, statutory authorization for punitive damages is unusual, and courts seem reluctant to take the initiative in fashioning such remedies. The common law traditionally allowed punitive damages only in a narrow class of torts where the injurer typically harmed the victim's dignity, such as slander. American state courts and legislatures, however, have expanded this practice beyond dignitary torts to allow punitive damages in many different kinds of civil cases, provided the defendant's behavior is bad enough.

The standard for "bad enough" is set so high that few cases qualify. Most states have a statute concerning the incidence and extent of punitive damages. According to the usual formulation, punitive damages can be awarded when the defendant's behavior is malicious, oppressive, gross, willful and wanton, or fraudulent. The statutes typically identify factors for the court to consider when setting the amount of punitive damages, including the seriousness of the wrong and the ability of the defendant to pay damages. ${ }^{6}$

These phrases provide guidelines for courts, but the guidelines have never been formulated into rules. Punitive damages are supposed to bear a "reasonable relationship" to compensatory damages, but the law does not prescribe anything definite. For example, the law does not say whether punitive damages should exceed compensatory damages by two times or 100 times. In the typical case involving punitive damages, the jury is asked to decide whether punitive damages should be awarded, and, if so, how much to award. The jury, however, does not receive definite instructions for answering either question. Instructions are so thin that the jury's intuitions determine damages.

Since juries receive minimum guidance from judges, awards are unpredictable. To illustrate, the ratio of punitive damages to compensatory damages awarded recently by juries falls as low as $1 / 10$ and rises to a number approaching infinity as compensatory damages approach zero. ' In one recent case, the

5. See Clayton Act $\S 14,15$ U.S.C. $\S 15$ (1994).

6. See, e.g., CAl. CIv. CODE $\$ 3294$ (a) (West 1998). The California Civil Code provides the following: "In an action for the breach of an obligation not arising from contract, where the defendant has been guilty of oppression, fraud, or malice, the plaintiff, in addition to the actual damages, may recover damages for the sake of the example and by way of punishing the defendant." That is not much detail to decide disputes involving millions of dollars.

7. The ratio of $1 / 10$ is found in William M. LANDES \& RICHARD A. POSNER, THE ECONOMIC STRUCTURE OF TORT LAW 305 tbl.10.7 (1987). 
jury awarded $\$ 3$ billion in punitive damages. ${ }^{8}$ Many private insurance contracts do not cover liability for punitive damages, and some states outlaw insurance against liability for punitive damages. Although rarely awarded, punitive damages represent a significant risk to some American defendants. Little wonder that defendants continue to argue (without success so far) that punitive damages fall under the prohibition of excessive fines by the Eighth Amendment to the United States Constitution. ${ }^{9}$ Jury intuition about the extent of punishment provides an uncertain and unstable foundation for law.

\section{III}

\section{WHY PUNISH?}

In economic models of liability, "perfect compensation" leaves the victim indifferent between no harm and harm with compensation. ${ }^{10}$ In other words, perfect compensation restores the victim to the same indifference curve as if no injury had occurred. A liability system with perfect compensation would make victims indifferent about the behavior of injurers. If victims are indifferent, then injurers should be free to decide how to act. These facts pose the theoretical question, "Why not permit everything and hold injurers liable for the consequences?" To develop the foundation for a theory of punitive damages, I will sharpen this question and answer it.

\section{A. Internalize or Deter?}

Permission to do something, provided that one pays a price set by the court, has been called a liability right. To illustrate, companies may be permitted to engage in activities that create a nuisance provided that they compensate the victims. ${ }^{11} \quad$ Alternatively, law may forbid people to harm others and punish those who intentionally violate the prohibition. To illustrate, law and morality forbid people to commit fraud or drive recklessly.

Liability rights and prohibitions locate decisions differently. For a liability right, the injurer is free to decide whether or not to act, provided he pays damages. In contrast, punishment subordinates the individual's freedom to the group's judgment about right and wrong. With a liability right, perfect compensation internalizes the harm caused by the injurer. With a prohibition, punishment ideally deters wrongdoing.

To understand deterrence, consider the parallel between victim's compensation and injurer's disgorgement. Disgorgement makes the injurer give up his

8. The $\$ 3$ billion dollar award was reduced on appeal in Pennzoil v. Texaco, 729 S.W.2d 768 (Tex. App. 1987). For an analysis of the litigation between Pennzoil and Texaco, see Robert Mnookin \& Robert Wilson, Rational Bargaining and Market Efficiency: Understanding Pennzoil v. Texaco, 75 VA. L. REV. 295 (1989).

9. See Browning-Ferris Industries of Vt., Inc. v. Kelco Disposal Inc., 492 U.S. 257 (1989).

10. The concept of perfect compensation is explained and developed in several passages in ROBERT COOTER \& THOMAS ULEN, LAW AND ECONOMICS 297-98, 363-65, 444-48 (1996).

11. See Boomer v. Atlantic Cement Co., Inc., 257 N.E.2d 870, 873 (N.Y. 1970). 
gains from the injury. "Perfect disgorgement" is a sum of money that leaves the injurer indifferent between the injury with liability for damages or no injury. ${ }^{12}$ In other words, perfect disgorgement restores the injurer to the same indifference curve as if no injury had occurred. Damages that exceed the amount required for perfect disgorgement are extra-disgorging. Extra-disgorging damages make the injurer worse off than if he had not committed the injury.

By definition, an injurer is indifferent between no injury and an injury with liability for perfectly disgorging damages. Consequently, an injurer who faces certain liability for extra-disgorging damages prefers not to cause the injury. When the liability system works perfectly, liability for extra-disgorging damages deters intentional wrongdoing.

TABLE 1

LIABILITY RIGHT VERSUS PROHIBITION

\begin{tabular}{cccc}
\hline & Injurer's Act & Law's Goal & Damages to Achieve Goal \\
\hline Liability Right & Permitted & Internalize & Perfect Compensation \\
Prohibition & Forbidden & Deter & Extra-disgorging
\end{tabular}

Table 1 summarizes the contrast between a liability right and a prohibition. A liability right gives freedom to injurers and perfect compensation fully protects victims. Furthermore, when the liability system works perfectly, liability for perfectly compensatory damages causes a potential injurer to balance his costs of precaution and the victim's costs of harm, as required for economic efficiency. Liability for perfectly compensatory damages provides incentives for efficient precaution by injurers in many economic models. ${ }^{13}$ In contrast, a prohibition forbids wrongdoing and deters it with extra-disgorging damages.

Notice that Table 1 implicitly suggests two different baselines for deciding when damages become punitive. Damages may be described as punitive when they exceed the amount required to compensate the plaintiff for the injury. According to this definition, punitive damages are extra-compensatory. Alternatively, damages may be described as punitive when they exceed the amount required for the injurer to disgorge the gain from wrongdoing. According to this definition, punitive damages are extra-disgorging. The two definitions of punishment reverse the role of victim and injurer in the baseline.

Although similar in form, damages computed under one definition do not generally equal damages computed under the other definition. The two con-

12. Perfect disgorgement is defined and analyzed in Robert D. Cooter \& Bradley J. Freedman, The Fiduciary Relationship: Its Economic Character and Legal Consequences, 66 N.Y.U. L. REV. 1045 (1991).

13. The first formalization of this idea for torts is in John Brown, Toward an Economic Theory of Liability, 2 J. LEGAL STUD. 325 (1973). Perfect compensation also destroys the victim's incentives for precaution. Any modern discussion of bilateral precaution explains the problem. For example, see COOTER \& ULEN, supra note 10 , at 365, 409, 435. 
cepts of punishment are not materially equivalent. When the goal of law is to deter injurer's from committing forbidden acts, the injurer's gain, not the victim's loss, provides the correct baseline for computing damages. Under ideal conditions - including certain liability-a small increment added to perfectly disgorging damages will deter. When liability is uncertain, the increment must increase enough to offset the uncertainty, as I discuss later in detail. The ideal conditions, which are unrealistic but useful for analysis, include no court errors and actors who are rational, informed, and solvent.

\section{B. Channeling Transactions}

Now I return to the question, "Why not permit everything and hold injurers liable for the consequences?" A variety of answers can be found both within and outside of the framework of economic analysis. Some scholars who work within the economic framework concentrate on the desirability of channeling transactions through markets rather than courts. To illustrate, the law prohibits you from stealing my golf clubs. If you want them, you have to buy them from me. Alternatively, the law might permit you to steal my golf clubs and compensate me. For most transactions, the market determines values at less cost than a court. For example, the market determines how much I value my golf clubs at less cost than a court can determine liability. So protecting my entitlement by a property right rather than a liability right saves transaction costs by channeling transactions into markets and away from courts. When markets can price goods at lower transaction costs than courts, prohibitions provide a more efficient structure for transactions than liability.

\section{Uncompensable Losses}

Instead of the transaction structure, I focus on a different reason why efficiency sometimes requires prohibitions rather than liability. Implementing perfect compensation is easy when the harmed object has a perfect substitute in the market. To illustrate, if one motorist destroys another's automobile, the market price enables the court to estimate perfectly compensatory damages. Implementing perfectly compensating damages is difficult when the injury harms a unique object with an imperfect substitute, such as an oil painting. Implementing perfect compensation may be impossible when the injury seriously harms a subject rather than an object. To illustrate, a parent may feel that no amount of money could make him indifferent over the death of his child. If a grieved parent feels that way, then perfectly compensatory damages are impossible in principle. Impossibility comes from the fact that the parent cannot make any sense out of the idea of being indifferent between his child and money. (Some scholars conclude that money and children's lives are incommensurable. $\left.{ }^{14}\right)$

14. See Margaret Jane Radin, Compensation and Commensurability, 1993 DuKE L.J. 56, 67; Cass R. Sunstein, Is the Rule of Law Good? (1994) (paper read at first draft of Tanner lectures). See gener- 


\section{Liability for Uncompensable Losses}

In spite of this fact, courts routinely award "compensatory damages" to the victims of uncompensable harms. In cases where compensation is impossible, the phrase "compensatory damages" badly misleads people concerning the purpose of damages. Legal language obscures another purpose for damages in such cases. The purpose is to deter people from exposing others to unreasonable risks. I will explain how to implement this goal through damages.

Social norms often restrict and regulate behavior that causes uncompensable losses. To illustrate, conventional morality forbids assault. Similarly, current social norms in California apparently require the driver to make sure that all children in cars use seat belts. Social norms, however, often do not stipulate the damages owed to victims of wrongdoing. To illustrate, social norms do not specify how much to compensate someone who was punched in the nose or who lost a child in an accident. Given these facts, juries find obligations more reliably than they do damages. For example, juries feel more confident about an obligation to reduce a particular risk to a child's life than about the damages that would compensate the parent if the risk materializes.

When compensation is impossible, an appropriate goal of liability law is to deter wrongdoers from violating community standards. Setting damages at the appropriate level makes rationally self-interested people conform to social norms. To illustrate, successful deterrence prevents adults from exposing children to more risk than allowed by social norms. I can describe the method of computing damages for deterrence by using Judge Hand's notation from United States v. Caroll Towing, Co. ${ }^{15}$

Let $B$ denote the burden of care, let $p$ denote the reduction in the probability of an accident caused by taking $B$, and let $L$ denote liability. Judge Hand had in mind a situation where no community standard exists. If there is no community standard, Judge Hand required the actor to take precaution until the burden is at least as great as the reduction in expected liability: $B>p L$.

I have in mind a different situation where a community standard exists but the harm is uncompensable. The community standard establishes the burden $B$ whose omission constitutes negligence. Objective facts establish the reduction in the probability $p$ of an accident caused by $B$. Given $B$ and $p$, the court should compute $L$ by solving $L=B / p$. I call this approach the "risk equivalent" method, because it aims for equivalence between money and the risk, not equivalence between money and the loss. ${ }^{16}$

ally Symposium, Law and Incommensurability, 146 U. PA. L. REV. 1169 (1998); Bruce Chapman, Law, Incommensurability, and Conceptually Sequenced Argument, 146 U. PA. L. REV. 1487 (1998).

15. 159 F.2d 169 (2d Cir. 1947).

16. I explain the "risk-equivalence" method for computing damages in COOTER \& ULEN, supra note 10 , at $306-08$. The unfortunate phrase more generally used in the law and economics literature is "hedonic indexes." For an account of their use, see W. Kip Viscusi, Comment on John Calfee and Clifford Winston's "The Consumer Welfare Effects of Liability for Pain and Suffering: An Exploratory Analysis," in BROOKINGS PAPERS ON ECONOMIC ACTIVITY: MICROECONOMICS 175 (Martin Neil Bailey et al. eds., 1993). For an imaginative example of their use, see John E. Calfee \& Clifford W. 
To illustrate, consider the computation of damages for the accidental death of a child. Courts find standards of negligence in social norms and refine them. If social norms as found by courts require an actor to spend $\$ 100$ on precautions to reduce the probability of a child's accidental death by .0001 , then the equivalent value of the risk equals $\$ 100 / .0001$, or $\$ 1$ million. In this example, the burden $B$ equals $\$ 100$, the probability $p$ equals .0001 . These facts imply that the liability $L$ should equal $\$ 1$ million.

Rationally self-interested actors decide whether or not to conform to the legal standard of care by balancing the costs of precaution and the expected costs of liability. The risk-equivalent method sets liability at the level that causes such actors to conform to the legal standard. When $L=B / p$, a rational actor will pay up to $B$ to avoid facing liability with probability $p$. For example, when faced with liability of $\$ 1$ million, the rationally self-interested actor will spend up to $\$ 100$ to reduce the probability of being liable by .0001 . To illustrate concretely, a profit-maximizing bottler of Coca-Cola will spend up to $\$ 100$ on quality control to reduce by .0001 the probability of being liable in tort for $\$ 1$ million. ${ }^{17}$

Current regulations create incentives for irrational and inconsistent levels of precaution. To illustrate, Viscusi found that the cost per life saved by various regulations varies from $\$ 100,000$ for unvented space heaters to $\$ 72$ billion for the 1987 formaldehyde standard. ${ }^{18}$ The risk-equivalent method for computing liability can help to rationalize precautions by providing uniform incentives. To illustrate, $\$ 1$ million in liability for the wrongful death of a child creates incentives for firms to spend $\$ 100$ on precaution to reduce the probability of death by .0001 , regardless of whether the firm manufacturers space heaters or formaldehyde.

\section{E. Bad Names}

Sometimes the legal methodology for computing compensatory damages omits categories of harm. To illustrate, the law may fail to compensate fully for consequential damages, remote damages, economic losses, exposure to risk, emotional distress, or pain and suffering. To achieve the goal of internalization, the law needs to fill the gap between allowed compensation and perfect compensation. One way to fill the gap is by allowing additional damages and calling them "punitive."

Winston, The Consumer Welfare of Liability for Pain and Suffering: An Exploratory Analysis, in BROOKINGS PAPERS ON ECONOMIC ACTIVITY 133 (1993).

17. The same proposition can be stated in terms of "perfect disgorgement," which I defined as the damages that leave the injurer indifferent between doing right and doing wrong. A rationally selfinterested actor must face damages of $\$ 1$ million in order to be indifferent between committing a wrong that results in liability with probability .0001 or doing right at a cost of $\$ 100$. A distinction can be drawn between ex ante and ex post disgorgement. From the ex ante viewpoint, perfect disgorgement of the expected gain from wrongdoing requires damages equal to $\$ 1$ million. From the ex post viewpoint, perfect disgorgement of the actual gain from wrongdoing requires damages equal to $\$ 100$.

18. See W. Kip Viscusi, Regulating the Regulators, 63 U. CHI. L. REV., 1423, 1432-35 (1996). 
Gap filling was apparently one of the original inspirations for awarding punitive damages in common law cases involving dignitary torts. To illustrate, consider the difficulty of estimating the damages required to compensate perfectly for the indignity of getting insulted and punched in the nose while peacefully enjoying a beer in a public house. Courts lack a methodology for computing compensatory damages in such cases. Punishment might fill the methodological gap and provide damages approximating the amount required for compensation.

Applying "punitive" to gap-filling damages spreads confusion. If the law's goal is perfect compensation of the victim, then the court should not use language suggesting that its goal is punishing the injurer. Instead, the law should adopt the best available methodology for implementing perfectly compensatory damages and say so. The best method to pursue a goal will advance it farther than pursuing a different goal by a better method.

IV

\section{WHEN TO PUNISH}

Channeling activities into voluntary transactions and deterring uncompensable harms sometimes requires backing prohibitions with penalties. Now I turn to the problem of when to impose punitive damages on wrongdoers. One writer has described a theory that judges and juries award punitive damages when, upon hearing the facts, they grip the arms of their chairs and think, "Oh my God!" ory of punitive damages by trying to explain such behavior.

\section{A. Commitment and Indignation}

Moral commitment increases trust, which makes cooperation easier and more productive. In a cooperative venture, people often get paid according to their contribution. Consequently a person who can signal moral commitment often gains an advantage in cooperative activities. ${ }^{20}$ Signaling commitment is difficult, however, because people can fake moral commitment. Gaining an advantage by commitment requires signaling that it is genuine.

Feelings can help to distinguish between fake and genuine commitment. Genuine moral commitment has an emotional aspect. People feel committed to internalized values. This connection between commitment and emotion has a useful function. Telling a cool lie is easier for many people than faking emotion. For example, a child who can tell a cool lie is often incompetent at faking emotion. Aspiring actors devote much time and effort to perfecting the art of faking emotion. Since faking emotion is difficult, the emotion attached to the

19. See David M. Burrell, A New Approach to the Problem of Wilful and Wanton Misconduct, 1949 INS. L.J. 716, 723.

20. For a comprehensive examination of signaling commitment to social norms, see generally Eric A. POSNer, LAw, CoOperation, ANd Rational Choice (1998). 
expression of moral commitment helps authenticate it. According to one theory, emotions evolved among people partly to provide the means to signal commitment. $^{21}$

Whereas economic rationality seems relatively cool, discussions of law can become relatively hot. The heat comes from the connection between emotion and commitment. People feel committed to values at issue in contested law, such as abortion, discrimination, or even closing the range to cattle. The presence of emotion suggests a prominent role in law for expressing internalized values. People who internalize social norms feel righteous anger against those who violate them. The institution of punitive damages allows judges and juries to express righteous anger through speech and punishment.

\section{B. Systems of Social Norms}

Punitive damages express indignation through the language of the law and the magnitude of the punishment. Expression of emotions by the court demonstrates its commitment to the law in question. Perception of commitment can shape the expectations of citizens and change their behavior. Usually, perception of the court's commitment changes behavior marginally by deterring wrongdoing. Sometimes, however, perception of the court's commitment changes behavior dramatically.

The system of social norms determines whether signaling commitment causes marginal deterrence or dramatic change. With a uniquely stable equilibrium in the system of social norms, the law's sanction changes behavior marginally. In contrast, with multiple equilibria, some of which are unstable, the law's expression can sometimes change expectations dramatically and permanently. Jumps occur because the court's commitment focuses expectations on a new equilibrium. If coordination problems prevent people from reaching a higher standard of behavior to which they aspire, law can sometimes solve the coordination problem by urging people to achieve the higher standard.

\section{Graphs ${ }^{22}$}

Before turning to deterrence, however, I will elucidate the preceding discussion of legal expression with the help of some graphs. The reader who dislikes graphs can skip to the next section.

Many productive activities require cooperation among people. Norms provide a guide to organization and a basis for trust that facilitates cooperation. Organized activity typically increases production above the level obtainable without organization. Some organizations, however, are superior to others. Social norms do not automatically prescribe the most productive organization. In addition, organizations distribute power and status. Social norms do not

21. See Robert H. Frank, Passions within Reason: The Strategic Role of the EMOTIONS (1988).

22. This section is based upon Robert D. Cooter, Expressive Law and Economics, 27 J. LEGAL STUD. (forthcoming 1998). 
automatically distribute power and status fairly. I will briefly describe some formal characteristics of norms relevant to their efficiency and fairness.

A social norm imposes an obligation that partitions the set of possible actions into permitted and forbidden zones. People conform to a norm by staying in the permitted zone, and people violate a norm by entering the forbidden zone. When an actor adopts the pure strategy of doing right or the pure strategy of doing wrong, the resulting payoff depends upon the strategy pursued by others. I assume that doing right contributes to production by increasing trust and cooperation, whereas doing wrong reduces production by undermining trust and cooperation. For example, truth-telling and promise-keeping contribute to production by solving the principal-agent problem.

Given a socially productive norm, an increase in the proportion of wrongdoers decreases the productivity of cooperative relationships. A decrease in productivity reduces the payoffs to wrongdoers and rightdoers. Although everyone's payoffs fall, the reduction may be different for wrongdoers and rightdoers. These differences have important consequences for equilibria in the system of norms. In evolutionary equilibrium, all behavior that persists yields the same objective payoff. In one common pattern, as the proportion of wrongdoers increases, the payoffs to wrongdoers fall faster than the payoffs to rightdoers. This possibility results in a stable interior equilibrium.

Figure 1 depicts this possibility. The vertical axis represents the payoff, the horizontal axis represents the proportion of wrongdoers, one curve represents payoffs for conforming to the norm, and the other curve represents payoffs for violating the norm. The intersection in the curves depicts an interior equilibrium where rightdoers and wrongdoers receive the same expected payoff.

FIGURE 1

STABLE EQUILIBRIUM

Expected

Payoff

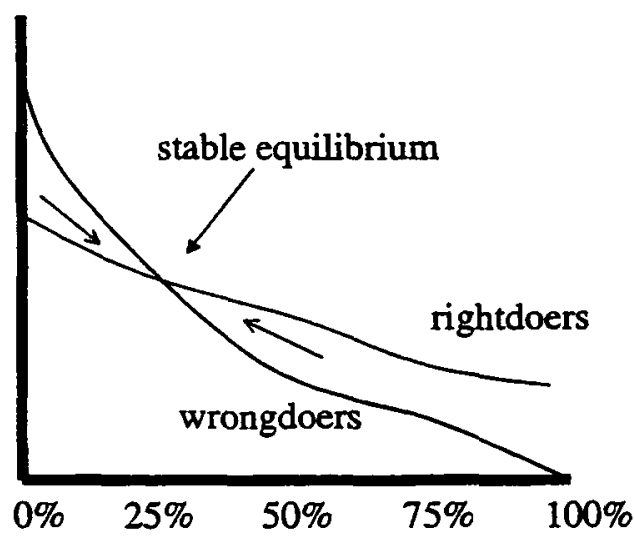

Proportion of Wrongdoers 
Now consider why the equilibrium is stable. If the proportion of wrongdoers increases beyond the equilibrium level, the payoff to rightdoers rises above the payoff to wrongdoers. With rightdoers receiving higher payoffs, some wrongdoers change their behavior. The number of wrongdoers declines until equilibrium is restored. Conversely, if the proportion of wrongdoers decreases below the equilibrium level, the payoff to wrongdoers rises above the payoff to rightdoers, so wrongdoers will increase in number until equilibrium is restored.

As explained, stability results from assuming that an increase in the proportion of wrongdoers harms wrongdoers more than rightdoers. Now change the assumptions and assume that an increase in the proportion of wrongdoers harms wrongdoers less than rightdoers. Figure 2 depicts this situation. The intersection of the curves represents an interior equilibrium that is unstable. Beginning from the interior equilibrium, an increase in wrongdoers causes the payoffs of wrongdoers to rise above the payoffs to rightdoers, so the number of wrongdoers continues to increase. The process ends at the stable equilibrium at the lower right corner where everyone does wrong.

FIGURE 2

UNSTABLE EQUILIBRIUM

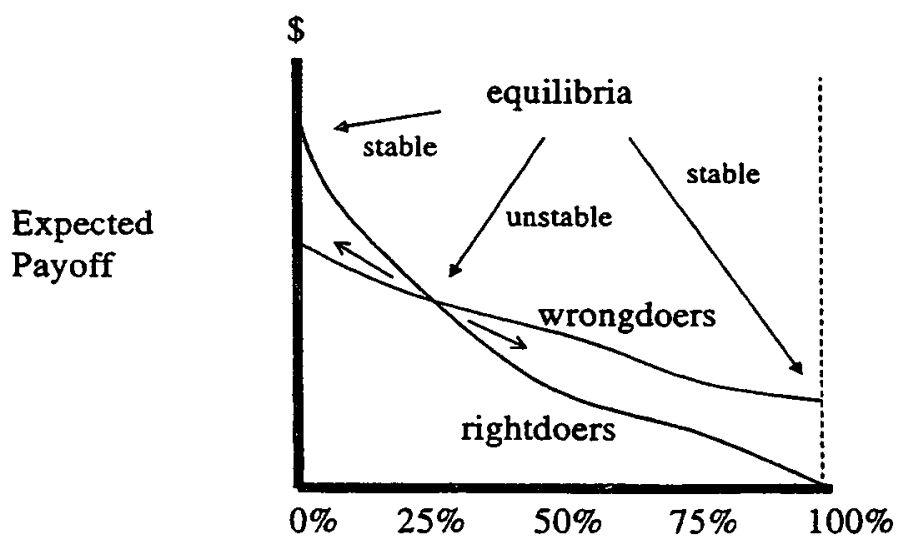

Proportion of Wrongdoers

Conversely, beginning from the unstable interior equilibrium, a decrease in wrongdoers causes the payoffs of wrongdoers to fall below the payoffs to rightdoers, so the number of rightdoers increases. The process ends at the stable equilibrium at the upper left corner where everyone does right.

For norms of cooperation, the curves expressing payoffs to rightdoers and wrongdoers slope down to express the loss in productivity as the proportion of wrongdoers increases. Theory, however, does not prescribe the gradient of the curves. The curves might intersect more than once. Figure 3 depicts this possi- 
bility. Figure 3 has a stable interior equilibrium with few wrongdoers, an unstable interior equilibrium with many wrongdoers, and a stable corner equilibrium with all wrongdoers. In Figure 3, the system stabilizes when few people $(25 \%)$ do wrong or when everyone $(100 \%)$ does wrong.

FIGURE 3

MULTIPLE EQUILIBRIA

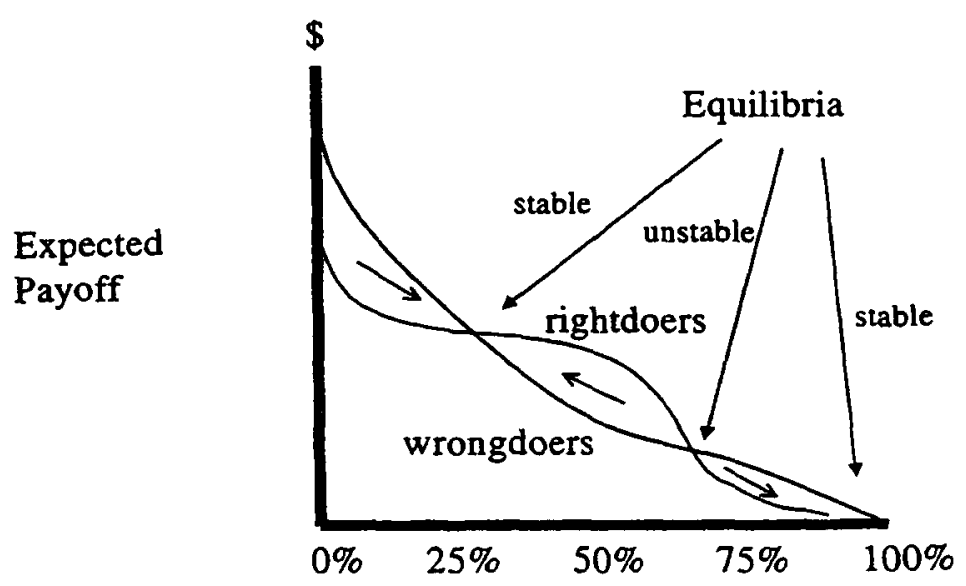

Proportion of Wrongdoers

Now I discuss how law can influence the systems of social norms depicted in Figures 1,2, and 3. Assume that lawmakers raise the social obligation to the level of a legal obligation and attach a sanction to its violation. The legal sanction causes the wrongdoer's payoff curve to shift down in the figures. If the wrongdoer's curve shifts down in Figure 1, then the equilibrium moves to the left. Because wrongdoing decreases, the new equilibrium has more cooperation and higher production. Given a stable interior equilibrium in the system of social norms, imposing legal sanctions deters wrongdoers marginally.

Deterrence, however, has different consequences in Figure 2. Recall that the interior equilibrium is unstable. Since the system does not settle at the interior equilibrium, small changes in the interior equilibrium have little or no consequences for the social system. ${ }^{23}$ Attaching a legal sanction to the social obligation causes the wrongdoer's payoff curve to shift down in Figure 2. A downward shift in the wrongdoer's payoff curve shifts the interior equilibrium and does not change the corner equilibria. Either everyone continues doing wrong, or else everyone continues doing right. In either case, the imposition of a legal sanction has no deterrence effect.

23. Changes in the interior equilibrium affect the size of the shock needed to cause the system to jump from one corner equilibrium to another corner equilibrium. 
Besides deterring wrongdoing, law coordinates expectations. Given a system of social norms with multiple equilibria, the coordination effects of law can be dramatic. In Figure 2, everyone does right or everyone does wrong. Assume that everyone does wrong. Now the state raises the social obligation to the level of law. If people respect law, enacting the obligation into law may cause people to change their expectations. If people think everyone else will switch from doing wrong to doing right, then the prophecy will fulfill itself. Enacting the law will cause the equilibrium to jump from the right corner, where everyone does wrong, to the left corner, where everyone does right.

The expressive theory of law represents an alternative to the deterrence theory of law. According to the expressive theory of law, the expression of social values is an important function of the courts, ${ }^{24}$ or possibly the most important function of the courts. ${ }^{25}$ The classical formulations, however, did not analyze the behavioral consequences of expressive law. The main finding of such an analysis is that, given multiple equilibria in a system of social norms, expression of legal commitments can cause dramatic jumps in behavior.

I have explained that legal sanctions change behavior marginally in a stable system of social norms, and legal expression can change behavior nonmarginally in an unstable system of social norms. In reality, normative systems are likely to be mixed, as depicted in Figure 3. In mixed systems of social norms, law can have deterrence effects and expression effects. To illustrate by using Figure 3, assume that the system of social norms is stuck at the right corner where $100 \%$ of the actors do wrong. A stable interior equilibrium exists where only $25 \%$ of the actors do wrong. Everyone's payoff would increase if the system could move from the corner equilibrium to the stable interior equilibrium.

Notice that the unstable, interior equilibrium in Figure 3 occurs with $70 \%$ wrongdoers and $30 \%$ rightdoers. In order to move to the stable interior equilibrium, at least $31 \%$ of the actors must change strategies and do right. Once $31 \%$ of the actors do right, rightdoers will continue to increase until $75 \%$ of the actors do right. Assume that enacting a law induces at least $31 \%$ of the citizens to change, so the system in Figure 3 moves to the stable interior equilibrium. Although improvement is dramatic, $25 \%$ of the actors continue doing wrong. Further reductions in wrongdoing would require deterrence. Supplementing social sanctions with legal sanctions shifts down the curve representing expected payoffs to wrongdoers in Figure 3, thereby reducing the equilibrium number of wrongdoers. Thus, the combination of expression and deterrence brings wrongdoing down to a low level.

24. For an argument that expressing social judgments is one of the uses of criminal law, see H.L.A. HART, PUNISHMENT AND RESPONSIBILITY (1968).

25. This was apparently Durkheim's view, as analyzed in DAVID GARLAND, PUNISHMENT AND MODERN SOCIETY: A STUDY IN SOCIAL THEORY 23-46 (1990). Note that I draw no connection between the emotive theory of law, which belongs to jurisprudence, and the emotive theory of the meaning of value, which belongs to epistemology. 
I have explained how law can change behavior dramatically in a social system with multiple equilibria. In such a social system, law can also fail dramatically. To illustrate concretely by Figure 3, recall that dramatic improvement occurs when, beginning from a situation in which everyone does wrong, enacting the law causes at least $31 \%$ of the actors to change and do right. Dramatic failures occur if less than $31 \%$ of the actors change and do right. Assume that enacting the law causes $25 \%$ of the actors to change and do right. The actors change from wrong to right because they expect other people to make the change. But not enough people make the change to sustain it. In that event, the system reverts to the original equilibrium where everyone does wrong.

In a system of social norms with a uniquely stable equilibrium, the law's sanction changes behavior marginally, but the law's expression cannot permanently change expectations or behavior. In a system of social norms with multiple equilibria, the law's sanction changes behavior marginally, and the law's expression dramatically succeeds or dramatically fails to change expectations and behavior. Using punitive damages for marginal deterrence risks little, whereas using law expressively risks a lot. The high risk of expression is that law can change social behavior dramatically or discredit itself.

\section{HOW MUCH TO PUNISH?}

Given the complexity of coordination problems and the fragility of symbols, I doubt that expressive theories of law can provide the basis for calibrating punitive damages. If punitive damages are based upon expressive law alone, the current problems of inconsistency have no remedy. Inconsistent awards of punitive damages muddle the message conveyed by the severity of punishment. For purposes of expression, the courts need a more consistent calibration of punitive damages than an expressive theory can provide. The goal of deterrence can provide a more consistent calibration of punishments. I will analyze the use of punitive damages for marginal deterrence, which leads to more precise conclusions about punishment.

I explained earlier that punitive damages arise only when the defendant behaved very badly. In the usual case, only intentional wrongs, or nearly intentional wrongs, are bad enough for punitive damages. The extent of damages thus depends upon distinguishing between intentional and unintentional wrongs. I will develop a distinction appropriate to an economic theory of damages.

\section{A. Lapses}

Table 1 describes incentive effects that influence rational actors. Tort liability, however, often arises from diminished rationality. Rationality diminishes when people mistakenly assess facts. In cases of unintended wrongs, the actor does not know that he is doing something wrong. To illustrate, I may drive too fast because I do not notice that I am near a school. When a wrong is 
unintended, the actor does not foresee possible punishment, so it cannot deter him. Similarly, in cases of under-appreciated risks, the actor under-estimates the risk that he imposes on others. To illustrate, I mistakenly think that asbestos dust poses only a small risk of lung cancer to my employees. When a risk is under-appreciated, liability will not cause the actor to internalize the full benefit of precaution.

Lapses in attention often cause unintended wrongs and under-appreciated risks. More vigilance by the actor reduces the frequency of lapses in attention. By "vigilance" I mean self-monitoring activities by which an actor controls his behavior. An account of rational self-monitoring provides the foundation for a theory of deterrence applied to unintended wrongs and under-appreciated risks.

A rationally self-interested actor balances the cost of self-monitoring and the reduction in expected liability from lapses. Liability for perfectly compensatory damages makes the injurer internalize the expected cost of harm. So, assuming certain ideal conditions including perfectly compensatory damages, a liability rule causes efficient self-monitoring by a rational actor. ${ }^{26}$

As explained, perfect compensation is impossible in principle for wrongs resulting in uncompensable harms. I propose to compute damages in such cases by the risk-equivalence method. Risk-equivalent damages create incentives to rationalize precaution. Specifically, risk-equivalent damages provide incentives to equalize the increase in safety obtained by investing more resources in all types of precaution, including self-monitoring. So, assuming certain ideal conditions including risk-equivalent damages, a liability rule causes efficient selfmonitoring by a rational actor.

The law often does not apply a legal standard to self-monitoring. To illustrate, consider failing to stop for a stop sign. Failing to stop at a stop sign is negligent, and the driver is liable for the consequences. Everyone, however, occasionally lapses and fails to stop at stop signs. The law, however, does not

26. The assumptions include costless, error-free application of liability rules by courts. Also included are certain assumptions about the connection between lapses and liability. Note that actors can have deficient incentives for self-monitoring under a negligence rule when some lapses result in nonnegligent injuries. For example, a lapse in my attention causes me to apply the breaks slower than otherwise, thus resulting in an accident. The law, however, may decide that I applied the breaks soon enough to satisfy the legal standard of care. Consequently, the law concludes that I was not negligent and not liable. In this example, I externalize part of the benefit of more intensive self-monitoring. Specifically, I externalize the reduction in non-negligent harms caused by more intensive selfmonitoring. In this case, liability law does not create incentives for efficient self-monitoring.

This problem cannot arise when all injuries caused by lapses result in liability. To illustrate, consider self-monitoring of stop signs by drivers. Every time I unintentionally run a stop sign, I am negligent and liable for the resulting harm. Consequently, I internalize the reduction in harm caused by more intensive self-monitoring of stop signs. I assume that self-monitoring to stop at stop signs does not spill over to the reduction of liability from accidents with causes other than failing to stop at stop signs.

In this discussion, I have not distinguished between the two major forms of the liability rule: strict liability and negligence. The former is simpler than the latter, but my generalizations hold with some qualifications under both rules. For an especially careful explanation of the difference in the context of punitive damages, see Polinsky \& Shavell, Punitive Damages, supra note 1, at 878-85. 
allow the driver to defend himself by proving that he inadvertently runs stop signs less often than most other people do. A high level of self-monitoring provides no defense for a lapse.

In this respect, self-monitoring by individuals resembles quality control by manufacturers. To illustrate, a Coca-Cola manufacturer has to monitor the bottles to make sure they contain no defects that could cause them to explode. More intensive and costly quality control results in fewer defective bottles. Defective bottles sometimes slip through even the best system of quality control. When a defective bottle injures a consumer, the law holds the manufacturer liable, without allowing a defense that its quality control was best. ${ }^{27}$ The manufacturer's quality control resembles the driver's self-monitoring, and the defective bottle resembles the driver running the stop sign. The court does not have the information to create and apply a standard of self-monitoring to individuals or a standard of quality control in manufacturing.

Now I return to the connection between intention and damages. Liability for unintended harms causes injurers to internalize the benefits of selfmonitoring. Thus liability for unintended harms causes actors to balance the cost of self-monitoring against the benefit of fewer lapses, as required for efficient incentives. Conversely, imposing extra-compensatory damages measured relative to the baseline of perfect compensation or risk-equivalent damages, provides incentives for excessive self-monitoring. In other words, extracompensatory damages create incentives for unreasonably costly vigilance. Thus the liability of injurers should typically equal, but not exceed, compensatory damages.

I used the concept of rational self-monitoring to build a theory of lapses. In this paper, I will not attempt to achieve greater realism by adjusting the model of rational self-monitoring in light of psychology. ${ }^{28}$

\section{B. Punishment}

Instead of lapsing, however, some actors impose excessive risk on others by intentionally violating standards of law and morality. Deterring their wrongdoing requires punishment. I will distinguish three motives for intentional wrongdoing, each with its own logic of deterrence.

First consider intentional wrongdoing motivated by errors in enforcing compensatory damages. To illustrate, assume that perfect compensation of the victim requires damages of $\$ 10,000$, and assume that problems of detection and proof cause the injurer to be held liable with probability $1 / 2$. An injurer's expected liability for compensatory damages thus equals $\$ 5,000$. Assume the cost of compliance with the legal standard of care costs $\$ 6,000$. Under these as-

27. See, e.g., Escola v. Coca-Cola Bottling Co., 150 P.2d 436 (Cal. 1944).

28. For a good discussion of the need for psychology to correct economics in the study of tort, see Gary T. Schwartz, Reality in the Economic Analysis of Tort Law: Does Tort Law Really Deter?, 42 UCLA L. REV. 377 (1995). 
sumptions, the rationally self-interested injurer intentionally does wrong in order to save $\$ 1,000$ in expected costs.

Punitive damages can offset enforcement errors and restore efficient deterrence to the liability system. In this example, a punitive multiple of $2 / 1$ restores the injurer's expected liability to $\$ 10,000$, as required for deterrence. Since the punitive multiple of $2 / 1$ equals the reciprocal of the enforcement error $1 / 2$, I call this method for computing punitive damages the rule of the reciprocal. ${ }^{29}$ The rule of the reciprocal applies to most cases of fraud by individuals and selfseeking by firms.

When applying the rule of the reciprocal, courts should not award punitive damages in cases like the Exxon Valdez, where an oil tanker ran aground. Since the whole world was sure to know about the accident, a rational actor like this large corporation would not expect to escape liability.

Some kinds of enforcement errors do not distort incentives and do not require correction by adjusting damages. Expected costs usually jump at the boundary between permitted and forbidden acts. Because of the jump in costs, most rational actors will conform to the legal standard in spite of enforcement errors. If costs jump by a large amount at the legal standard, then a damage multiple is unnecessary to offset enforcement errors and to deter wrongdoing by rational actors. Conversely, if costs jump by a small amount at the legal standard, then reciprocal damages are necessary to offset enforcement errors and to deter wrongdoing by rational actors. In general, the necessity of reciprocal damages to deter wrongdoing depends upon the relative size of the enforcement error and the jump in liability costs at the legal standard.

Malice is a second motive for intentional wrongdoing. The assailant who insults me and breaks my nose presumably derives something valuable from his act, such as satisfaction. Subjective satisfaction is difficult to observe and often impossible to measure. Consequently, no rule exists for computing the punishment required to deter malicious acts. Although tailoring punishment to individuals is difficult, statistical evidence can show the average relationship between punishment and deterrence. As with criminal fines, the calibration of punitive damages for malice must rely upon such aggregate statistics.

Self-seeking firms may pursue profits unscrupulously but not maliciously. Malicious acts by employees divert the firm's resources from the pursuit of profits. The directors and managers of the firm have an incentive to monitor employees to prevent the diversion of its resources. Consequently, malice by employees typically results from imperfect monitoring by the firm. Imperfect monitoring of employees by the firm resembles imperfect self-monitoring of the individual, which brings me to the next kind of wrongdoing.

A third motive for wrongdoing occurs in cases involving reckless disregard for the safety of others. Actors who disregard risks are often in special emo-

29. See Robert D. Cooter, Punitive Damages for Deterrence: When and How Much, 40 ALA. L. REV. 1143, 1148 (1989). For further discussion and mathematical notation, see COOTER \& ULEN, supra note 10 , at $506-45$. 
tional states, such as the young man suffering from Saturday night fever. Heightened emotions can cause excessive discounting of risk and futurity. In such circumstances, the actor needs the threat of punishment to acquire better discipline and control over his emotions. Efficient self-monitoring requires punitive damages in such cases, not merely compensatory damages. Social scientists have not developed or tested precise theories about how punishing reckless behavior causes people to gain self-control. (An elaboration of the model of lapses can provide the foundation for developing such a model. ${ }^{30}$ ) Consequently, I know of no rule for computing optimal punishment in such cases.

A similar analysis applies to a firm. Idiosyncratic directors and managers may apply very high discount rates to risk and futurity, which results in reckless behavior. Deterring such behavior requires the punishment of the directors and managers. I know of no rule for computing optimal punishment in such cases. Similarly, a lapse in monitoring by directors and managers may allow a deviant employee recklessly to endanger customers or the public. The imposition of punishment on the firm, as opposed to the individual wrongdoers, punishes the stockholders or consumers for not monitoring the directors, managers, or employees who committed the wrong.

\section{VI \\ CONCLUSION}

Law and morality forbid acts that cause uncompensable harms or create unreasonable risks. When people intentionally commit such acts, courts express anger and indignation at the wrongdoer through speech and punishment. Civil courts correctly draw upon the righteous anger of jurors over intentional wrongs to chastise the actor and harm his reputation. In a system of social norms with multiple equilibria, expressions of emotion signal commitment and coordinate expectations. In a system of social norms with a unique, stable equilibrium, sanctions deter marginally. Social norms, however, provide a better guide to the need for punitive damages than to their extent. Courts make a serious error in asking jurors to assign punitive damages without providing detailed instructions on their computation. The court in a typical case should impose the minimum punishment required to deter wrongdoing.

30. See the model of imprudence in Robert D. Cooter, Self-Control and Self-Improvement for the "Bad Man" of Holmes, 78 B.U. L. REV. (forthcoming 1998). In an earlier paper on lapses, I argued that optimal deterrence of wrongdoing caused by excessive discounting of future punishments could be effected by applying mild fines with high probability. See Robert D. Cooter, Lapses, Conflict, and Akrasia in Torts and Crimes: Towards an Economic Theory of the Will, 11 INT'L REV. L. \& ECON. 149 (1991) (reversing Becker's classic formula in which optimal deterrence requires severe fines with low probability). For Becker's formula, see Gary Becker, Crime and Punishment: An Economic Approach, 76 J. POL. ECON. 169 (1968). 
HeinOnline -- 60 Law and Contemp. Probs. 921997 